\title{
Changes in the activities of glutathione-S-transferases, glutathione reductase and catalase after exposure to different concentrations of cadmium in Australoheros facetus (Cichlidae, Pisces)
}

\author{
A.C. Crupkin ${ }^{1} \&$ M.L. Menone ${ }^{1,2,3}$ \\ ${ }^{1}$ Facultad de Investigaciones Marinas y Costeras (IIMyC) CONICET/ UNMdP. Fac. Cs. Ex. y de Cs. Ex. y Nat. Lab. \\ Ecotoxicología. Funes 3350 (7600) Mar del Plata, Argentina. \\ ${ }^{2}$ Instituto de Investigaciones Marinas y Costeras (IIMyC) CONICET/ UNMdP. Fac. Cs. Ex. y Nat. Funes 3350 (c.p. 7600$)$ Mar del Plata. \\ ${ }^{3}$ Consejo Nacional de Investigaciones Científicas y Técnicas (CONICET).
}

(Received December 21, 2011; Accept January 16, 2012)

\begin{abstract}
The goal of this work was to evaluate the response of the glutathione-S-transferases (GST), glutathione reductase (GR) and catalase (CAT) enzymes in different tissues of the fish Australoheros facetus exposed cadmium (Cd). In liver, a significant decrease of GST activity was observed at $0.031 \mathrm{mg} \mathrm{L}^{-1}(\mathrm{p}<0.05)$, while, at higher concentrations, there were non-significant changes compared to controls. Neither the GR nor the CAT activity was different from control. Gills was the most sensitive organ, showing increased GST activity at 0.31 and $1.53 \mathrm{mg} \mathrm{L}^{-1}$ and $\mathrm{GR}$ at $3.06 \mathrm{mg} \mathrm{L}^{-1}$; while CAT activity was inhibited at $0.31,3.06$ and $6.13 \mathrm{mg} \mathrm{L}^{-1}(\mathrm{p}<0.05)$. The brain GST activity was increased at $1.53 \mathrm{mg} \mathrm{L}^{-1}$ but inhibited at 3.06 and $6.13 \mathrm{mg} \mathrm{L}^{-1}$, meanwhile GR and CAT activities were inhibited at $1.2,3.06$ and $6.13 \mathrm{mg} \mathrm{L}^{-1}(\mathrm{p}<0.05)$. The induction of defense enzymes as well as the inhibition of the antioxidant enzyme catalase, even at environmentally relevant concentrations used in this work (e.g. $0.31 \mathrm{mg} \mathrm{L}^{-1}$ ), denotes the toxic effect that cadmium exerts over the tissues of $A$. facetus and alerts over the need of doing biomonitoring in areas potentially polluted with metals.
\end{abstract}

Keywords: biomarkers, cadmium, catalase, glutathione reductase, glutathione-S-transferases.

Cambios en las actividades de glutation-S- transferasa, glutation reductasa y catalasa en Australoheros facetus (Cichlidae, Pisces) expuesto a diferentes concentraciones de cadmio

\section{Resumen}

El objetivo de este trabajo fue evaluar la respuesta de las enzimas glutatión-S-transferasa (GST), glutatión reductasa (GR) y catalasa (CAT) en diferentes tejidos del pez Australoheros facetus expuesto a cadmio (Cd). En hígado, se observó una disminución de la actividad de GST a $0,031 \mathrm{mg} \mathrm{L}^{-1}(\mathrm{p}<0,05)$, mientras que a concentraciones mas elevadas no se hallaron diferencias respecto al control. La branquia fue el órgano mas sensible, presentando un incremento de actividad de GST a 0,31 y $1,53 \mathrm{mg} \mathrm{L}^{-1} \mathrm{Cd}$ y de GR a 3,06 $\mathrm{mg} \mathrm{L}^{-1} \mathrm{Cd}$; mientras que la actividad de CAT resultó inhibida a $0,31,3,1$ y $6,13 \mathrm{mg} \mathrm{L}^{-1} \mathrm{Cd}^{-1}$ $(\mathrm{p}<0,05)$. En el cerebro la actividad de GST se incrementó a $1,53 \mathrm{mg} \mathrm{L}^{-1} \mathrm{Cd}$ y se inhibió a 3.1 y $6,13 \mathrm{mg} \mathrm{L}^{-1} \mathrm{Cd}$, mientras que las actividades de GR y CAT se inhibieron a 1,53, 3,1 y 6,13 $\mathrm{mg} \mathrm{L}^{-1} \mathrm{Cd}(\mathrm{p}<0,05)$. La inducción de los sistemas de defensa así como la inhibición del enzima antioxidante catalasa, aún a concentraciones de relevancia ambiental (ejemplo $0,31 \mathrm{mg} \mathrm{L}^{-1}$ ), demuestra el efecto tóxico que ejerce el $\mathrm{Cd}$ en los tejidos de $A$. facetus y alerta sobre la necesidad de realizar biomonitoreos en áreas potencialmente contaminadas con metales pesados.

Palabras clave: biomarcadores, cadmio, catalasa, glutatión reductasa, glutatión-S-transferasas.

*Corresponding author: Dr. Mirta L. Menone; e-mail: lujanm@mdp.edu.ar 


\section{INTRODUCTION}

Metals can cause an increase in reactive oxygen species (ROS) leading to oxidative damage. Cadmium (Cd) binds to complex III in the electron transport chain promoting the production of ROS (Boelsterli, 2007). Under oxidative stress, antioxidant defenses are induced to protect animal organisms from free radicals as the first line of defense against $\mathrm{Cd}$, before the induction of any other detoxification mechanism (Basha \& Rani, 2003). In the aquatic environment fishes are exposed to different classes of pollutants being the metals one of the major group of aquatic contaminants. In fact, all water bodies are polluted by metals, elements as mercury $(\mathrm{Hg})$, cadmium $(\mathrm{Cd})$, copper $(\mathrm{Cu})$, and zinc $(\mathrm{Zn})$ are considered the most dangerous in the ecotoxicological aspect (Golovanova, 2008). Although in general the environmental levels of $\mathrm{Cd}$ do not exceed guideline values $\left(<0.25 \mathrm{ug} \mathrm{L}^{-1}\right.$, SRHN, 2003), aquatic organisms are able to accumulate this chemical up to concentrations that are tens and even thousands of times higher than their concentrations in the environment (Golovanova, 2008). Therefore, sublethal concentrations in water can lead finally to toxic effects in biota. In particular, values of cadmium as high as $0.7-1.7 \mathrm{mg} / \mathrm{L}$ have been reported in surface water in Argentine (Salibián, 2006) alerting about its potential effects in the freshwater biota.

Australoheros facetus is a common freshwater species distributed in Argentine, Brazil, Uruguay and Paraguay (Rican \& Kullander, 2006). It is easy to maintain, grow and reproduce in the laboratory (Bulus Rossini \& Ronco, 2004). It is sensitive to metals and to $\mathrm{Cd}$ in particular, showing a $\mathrm{LC}_{50}$ of $0.091 \mathrm{mg} \mathrm{L}^{-1}$ in 15-days old (post-hatch) organisms, dying within $96 \mathrm{~h}$. When comparing the relative sensitivity of this species, the following trend, from the most to the least toxic, can be seen: $\mathrm{Cd}(\mathrm{II})>\mathrm{Hg}(\mathrm{II})>\mathrm{Cu}$ (II) $>\mathrm{Zn}$ (II) $>\mathrm{Cr}$ (VI) (Bulus Rossini \& Ronco, 2004). Our work is the first report concerning sublethal effects of $\mathrm{Cd}$ in adult organisms from the same species.

Taking into account that activities of enzymes can vary greatly among different tissues within the same organism (Huggett et al., 1992) the goal of the present work was to evaluate changes in the activities of glutathione-S-transferases (GST), gluthione reductase (GR) and catalase (CAT) enzymes in liver, gill and brain tissues of the freshwater fish species Australoheros facetus exposed to environmentally relevant and higher concentrations of $\mathrm{Cd}$.

\section{MATERIALS AND METHODS}

\section{Fish exposure}

Fish were collected in freshwater bodies around Mar del Plata city (Province of Buenos Aires, Argentina, 37 53' South, $57^{\circ} 59^{\prime}$ West) and acclimatized to laboratory conditions prior to the experiments for one month in 140-L tanks. The experimental room was illuminated with fluorescent lamps with $12 \mathrm{~h}$ light periods. The tap water used for the experiments had a temperature of $20 \pm 1^{\circ} \mathrm{C}$, $\mathrm{pH}$ values of $8.2 \pm 0.2$, a total hardness of $374 \mathrm{mg} \mathrm{L}^{-1} \mathrm{CaCO}_{3}$ and alkalinity of $160 \mathrm{mg} \mathrm{L}^{-1} \mathrm{CaCO}_{3}$. A stock solution of $1 \mathrm{~g} \mathrm{~L}^{-1}$ of cadmium chloride $\left(\mathrm{CdCl}_{2}\right)$ (Sigma) was prepared in distilled water and aliquots were taken to prepare different exposure solutions in a final volume of $30 \mathrm{~L}$. The experiment was conducted in glass aquaria, each containing 6 fishes ( $\mathrm{n}=6$ per treatment) in $30 \mathrm{~L}$ of tap water (controls) and in contaminated test water. Fish were exposed during $24 \mathrm{~h}$ to $0,005,0.05,0.5,2.5,5$ and $10 \mathrm{mg} \mathrm{L}^{-1}$ of $\mathrm{CdCl}_{2}$ being the final concentrations of Cd: $0,0.0031,0.031,0.31,1.53,3.06$ and $6.13 \mathrm{mg} \mathrm{L}^{-1}$, respectively. At the end of the exposure period, all fishes were dissected using a fresh razor blade. Livers, gills and brains were sampled, weighed, immediately frozen using liquid nitrogen, and stored at $-80^{\circ} \mathrm{C}$ until analysis. The morphometric characteristics are shown in Table 1.

\section{Enzyme extraction}

The extraction of cytosolic enzymes was done according to the method described by Wiegand et al. (2000) without the purification step. Briefly, $50 \mathrm{mg}$ of each tissue material were used. Frozen tissues were homogeinized using a Potter glass homogenizer (packed in ice) with $5 \mathrm{~mL}$ sodiumphosphate buffer $(0.1 \mathrm{M}, \mathrm{pH} 6.5)$ containing $20 \%$ glycerol, $14 \mathrm{mM}$ 1,4- dithioerythritol (DTE), and $1 \mathrm{mM}$ EDTA. Cell debris was removed by centrifugation at $10,000 \mathrm{~g}$ for $10 \mathrm{~min}$. The supernatant was centrifuged at $100,000 \mathrm{~g}$ for $60 \mathrm{~min}$ to separate the membrane- associated fraction from the soluble fraction. The cytosolic fraction was immediately frozen using liquid nitrogen, and stored at $-80^{\circ} \mathrm{C}$ until measurement

Enzymatic activities were determined by spectrophotometry. The activity of the soluble (cytosolic) glutathione S-transferase (GST) was determined using 1-chloro-2, 4-dinitrobenzene (CDNB) as substrate, according to Habig et al. (1974). Glutathione reductase activity (GR) was assayed according to Tanaka et al. (1994) and catalase activity (CAT) according to Claiborne (1985). The enzymatic activities were estimated in

Table 1: Morphometric characteristics of Australoheros facetus after exposure to cadmium. Data are mean \pm standard deviation.

\begin{tabular}{ccccc}
\hline Treatment & Total Length $(\mathbf{c m})$ & Total Weight $(\mathbf{g})$ & Condition Factor (K) & Hepatic Index \\
\hline Control & $9.7 \pm 0.8$ & $22.6 \pm 6.3$ & $2.39 \pm 0.1$ & $4.6 \pm 1.0$ \\
$0.0031 \mathrm{mg} \mathrm{L}^{-1}$ & $9.7 \pm 0.5$ & $22.4 \pm 3.5$ & $2.40 \pm 0.1$ & $4.3 \pm 0.6$ \\
$0.031 \mathrm{mg} \mathrm{L}^{-1}$ & $9.9 \pm 0.3$ & $24.4 \pm 2.7$ & $2.47 \pm 0.1$ & $5.0 \pm 0.8$ \\
$0.31 \mathrm{mg} \mathrm{L}^{-1}$ & $9.8 \pm 0.9$ & $24.1 \pm 6.5$ & $2.45 \pm 0.1$ & $4.4 \pm 0.8$ \\
$1.53 \mathrm{mg} \mathrm{L}^{-1}$ & $10.1 \pm 1.0$ & $26.3 \pm 7.6$ & $2.48 \pm 0.1$ & $4.5 \pm 1.5$ \\
$3.06 \mathrm{mg} \mathrm{L}^{-1}$ & $10.0 \pm 1.0$ & $23.8 \pm 7.2$ & $2.28 \pm 0.2$ & $4.2 \pm 0.9$ \\
$6.13 \mathrm{mg} \mathrm{L}^{-1}$ & $9.7 \pm 0.9$ & $24.0 \pm 7.0$ & $2.53 \pm 0.3$ & $4.1 \pm 1.0$ \\
\hline
\end{tabular}


terms of the protein content for each sample (Bradford 1976), using a bovine serum albumin solution as standard. Enzymatic activities are reported in nano katals per milligram of protein (nkat. $\mathrm{mg}^{-1}$ prot), where 1 katal correspond to the conversion of $1 \mathrm{~mol}$ of substrate per second. Each enzymatic assay was carried out in duplicate. All reactive were purchased from Sigma.

\section{Statistics}

Differences between treatments were tested by nonparametric Kruskal-Wallis test and a posteriori by the MannWhitney U-test (Zar, 1999).

\section{RESULTS}

\section{Liver}

A significant decrease of GST activity was observed at $0.031 \mathrm{mg} \mathrm{L}^{-1} \mathrm{Cd}(\mathrm{p}<0.05)$, while, at higher concentrations, there were non-significant changes compared to controls. Neither the GR nor the CAT activity was different from controls ( $>>0.05$ ) (Fig. 1).

\section{Gills}

Increase of GST activity was observed at 0.31 and 1.53 $\mathrm{mg} \mathrm{L}^{-1} \mathrm{Cd}$ concentrations (Fig. 2). Glutathione reductase activity was significantly increased at $3.1 \mathrm{mg} \mathrm{L}^{-1}$ while CAT activity was significantly decreased at $0.31,3.1$ and $6.13 \mathrm{mg}$ $\mathrm{L}^{-1}(\mathrm{p}<0.05)$ (Fig. 2).

\section{Brain}

Increase of GST activity at $1.53 \mathrm{mg} \mathrm{L}^{-1} \mathrm{Cd}$ was observed $(\mathrm{p}<0.05)$ while at 3.1 and $6.13 \mathrm{mg} \mathrm{L}^{-1}$ the activity was lower
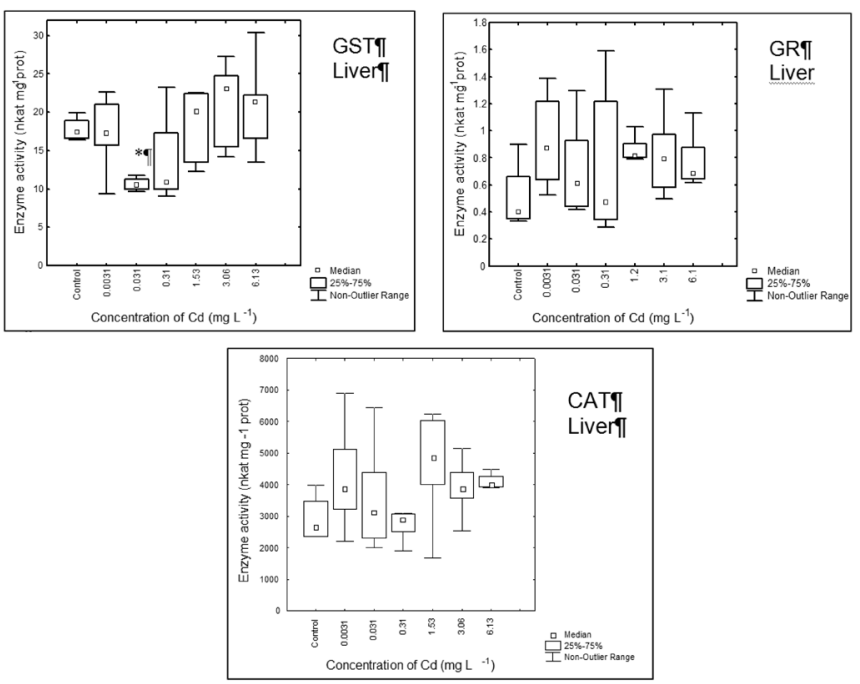

Figure 1: Concentration-response curve in liver of Australoheros facetus after exposure to cadmium. Data are median \pm standard error. Exposure time: $24 \mathrm{~h}$. *: significantly different to control $(\mathrm{p}<0.05)$. GST: glutathione-Stransferase, GR: glutathione reductase, CAT: catalase.
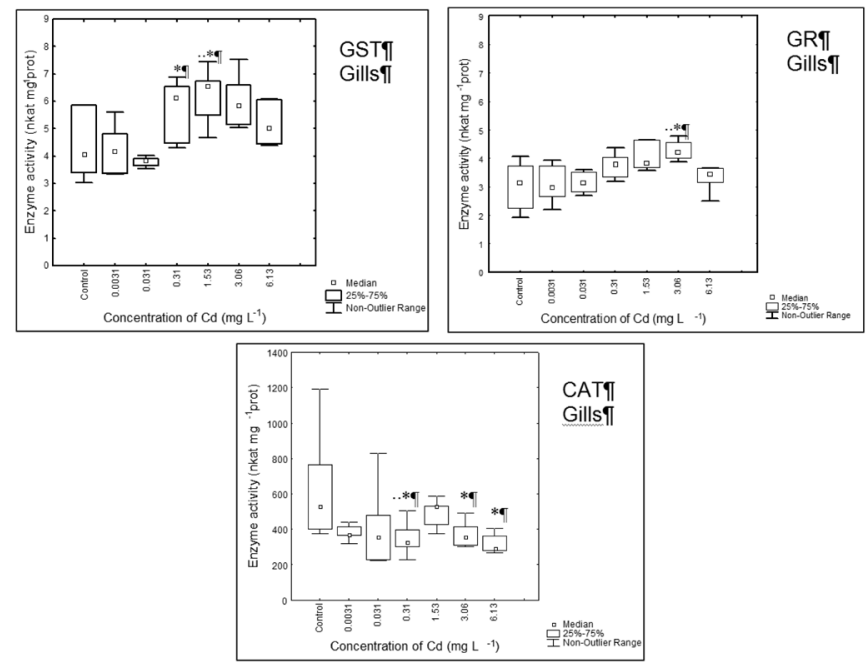

Figure 2: Concentration-response curve in gills of Australoheros facetus after exposure to cadmium. Data are median \pm standard error. Exposure time: 24 h. *: significantly different to control $(\mathrm{p}<0.05)$. GST: glutathione-Stransferase, GR: glutathione reductase, CAT: catalase.

than in control $(\mathrm{p}<0.05)$ (Fig. 3). At concentrations of 0.31, $1.53,3.1$ and $6.13 \mathrm{mg} \mathrm{L}^{-1} \mathrm{Cd}$, a 1.4-2.7-fold significant decrease of GR activity was detected ( $<<0.05$ ) (Fig. 3). A significant 2.1-2.6- fold decrease of CAT activity at Cd concentrations of $1.53,3.1$ and $6.13 \mathrm{mg} \mathrm{L}^{-1}$ was observed $(\mathrm{p}<0.05)$ (Fig. 3).

\section{DISCUSSION}

It has been previously shown that Cd exposure alters $\mathrm{GSH} /$ GSSG ratio in fish species such as rainbow trout (Lange et al., 2002). Glutathione-S-transferases constitute a complex family of proteins that play roles in both normal cellular metabolism and in the detoxification of a wide variety of xenobiotic compounds. They are predominantly cytosolic defence systems responsible for protecting cellular components against various toxic effects and oxidative stress (Sen \& Semiz, 2007). It has also been demonstrated that the role of GST in oxidative stress is of conjugating endogenously-produced electrophiles such as membrane lipid peroxides in animals (Halliwell \& Gutteridge, 1999) as well as in plants (Cummins et al., 1999). According to our present results, GST and GR could play a role in oxidative stress tolerance and could act protecting A. facetus against damages induced by $\mathrm{Cd}$, especially when other defence systems are not efficient, like CAT that was inhibited even with low Cd concentrations (e.g. $0.31 \mathrm{mg} \mathrm{L}^{-1}$ in gills). Cadmium induced enzymatic defences and when the enzyme activities are overwhelmed inhibited damage could occur. Although damage in A. facetus was not studied in this work, it represents a potential effect because oxidative damage measured as increased malondialdehyde (MDA) content as well as DNA fragmentation (Jia et al., 2010) and micronucleous (Ossana et al., 2009) have been reported at 0.5 $\mathrm{mg} \mathrm{L}{ }^{-1} \mathrm{Cd}$ in other fish species.

Brain is particularly susceptible to oxidative damages. In spite of the high rate production of ROS, from the high rate 
oxidative metabolism and abundance of polyunsaturated fatty acids in cell membrane, brain has a relatively low antioxidant defence system (Matés, 2000; Verstraeten et al., 2008). Although it has been reported that brain is not the main target organ of $\mathrm{Cd}$ in rats or that this metal it is not able to pass through the blood-brain barrier (Carrasco Trancoso, 2000), brain represent a sensitive target organ to Cd toxicity in $A$. facetus. This fact is clearly evidenced by the inhibition of the three enzymatic systems analyzed in the organ. Catalase has been shown to be either induced or inhibited by metals depending on the dose, the species and the route of exposure (Atli et al., 2006). The response of CAT observed in gills and brain could be due to the increased flux of superoxide radicals and hydrogen peroxide, which had been reported to inhibit CAT activity in other freshwater fishes possibly due to the direct binding of metal ions to -SH groups of the enzyme molecule (Pandey et al., 2001; Atli et al., 2006).

For many xenobiotics, the underlying mechanisms that govern their organotrophy or make a particular tissue prone to succumb to the resulting toxic effects are not known (Boelsterli, 2007). Fish gills constitute a direct exposure route for environmental water contaminants and it is the first organ affected when fishes are exposed to metals (Atli et al., 2006). In this study gills were more sensitive than liver. Also, brain has been proposed as more sensitive than liver and one of the most important target organs in fishes (Song et al., 2006). Because of that, both organs could be considered in future biomarkers evaluations. Our results extend the current knowledge by suggesting the participation of GST and GR as defence mechanisms against $\mathrm{Cd}$ in $A$. facetus since increased enzyme activities were observed in response to $\mathrm{Cd}$ exposure. On the other hand, the inhibition of CAT observed in gills and brain showed the oxidative stress caused by this metal.

Overall, the induction of defense enzymes as well as the inhibition of the antioxidant enzyme catalase, even at

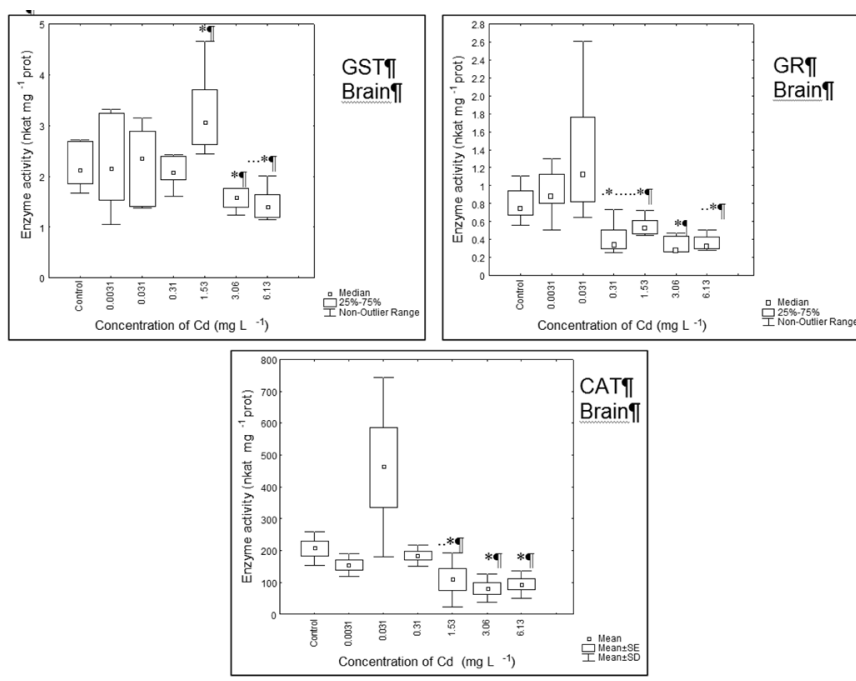

Figure 3: Concentration-response curve in brain of Australoheros facetus after exposure to cadmium. Data are median \pm standard error. Exposure time: $24 \mathrm{~h}$. *: significantly different to control $(\mathrm{p}<0.05)$. GST: glutathione-Stransferase, GR: glutathione reductase, CAT: catalase. environmentally relevant concentrations used in this work, denotes the toxic effect that cadmium exerts over the tissues of $A$. facetus and alerts over the need of doing biomonitoring in areas potentially polluted with metals.

\section{AKNOWLEDGEMENTS}

We would like to thank Chemist G. Bernava for physicochemical determinations of water samples, Juan Manuel Sallovitz for English revision, L. Chiodi and T.D. Gómez for assistance in laboratory work, and to D. Rodriguez for lend us the facilities to do the exposures. This work was supported by the following grants FONCYT-PICTR 2003-327, CONICET PIP 6497 and PICT 2005- 33228 BID 1728/OC- AR.

\section{REFERENCES}

ATLI, G., ALPTEKIN, O., TUKEL, S., CANTLI, M., 2006, Response of catalase activity to $\mathrm{Ag}^{+}, \mathrm{Cd}^{2+}, \mathrm{Cr}^{6+}, \mathrm{Cu}^{2+}$ and $\mathrm{Zn}^{2+}$ in five tissues of freshwater fish Oreochromis niloticus. Comp. Biochem. Physiol. Part C, 143: 218- 224. http://dx.doi. org/10.1016/j.cbpc.2006.02.003.

BASHA, P. \& RANI, A., 2003, Cadmium- induced antioxidant defense mechanism in freshwater teleost Oreochromis mossambicus (Tilapia). Ecotoxicol. Environ. Safety, 56: 218221. http://dx.doi.org/10.1016/S0147-6513(03)00028-9.

BOELSTERLI, U. A., 2007, Mechanistic Toxicology. The molecular basis of how chemicals disrupt biological targets, 2nd Edition, CRC Press Taylor \& Francis Group, Boca Raton, FL, USA.

BRADFORD, M. 1976, A rapid and sensitive method for the quantification of microgram quantities of protein utilizing the principle of protein- dyebinding. Anal. Biochem, 72: 248-254.

BULUS ROSSINI, G. D. \& RONCO, A. E., 2004, Sensitivity of Cichlasoma facetus (Cichlidae, Pisces) to Metals. Bull. Environ. Contam. Toxicol, 72: 762-768. http://dx.doi.org/10.1007/s00128004-0310-7.

CARRASCO TRANCOSO, J., 2000, Regulación de las Metalotioneínas durante el estrés y la inflamación, y su influencia durante la respuesta inflamatoria. Ph D Thesis Universidad Autónoma de Barcelona. Bellaterra.

CLAIBORNE, A., 1985, Catalase activity. In: Greenwald RA, editor. CRC handbook of methods in oxygen radical research. CRC Press, Boca Raton, FL, USA.

CUMMINS, I., COLE, D. J., EDWARDS, R., 1999, A role of glutathione transferases functioning as glutathione peroxidases in resistance to multiple herbicides in black- grass. Plant J., 18: 285-292. http://dx.doi.org/10.1046/j.1365-313X.1999.00452.x.

GOLOVANOVA, I. L. 2008, Effects of Heavy Metals on the Physiological and Biochemical Status of Fishes and Aquatic Invertebrates. Inland Water Biol., 1: 93-101. http://dx.doi. org/10.1007/ s12212-008-1014-1.

HABIG, W., PABST, M. J., JAKOBY, W. B., 1974, Glutathione Stransferase: the first step in mercapturic acid formation. J. Biol. Chem., 249: 1730-1739.

HALLIWELL, B. \& GUTTERIDGE, J. M. C., 1999, Free Radicals in Biology and Medicine. Oxford University Press, New York, USA.

HUGGETT, R. J., KIMERLE, R.A., MEHRLEJR.P. M., BERGMAN, H. L., 1992, Biomarkers. Biochemical, Physiological, and Histological Markers of Anthropogenic Stress, Lewis Publishers, Chelsea, MI. 347 pp. 
JIA, X., ZHANG, H., LIU, X. 2010, Low levels of cadmium exposure induce DNA damage and oxidative stress in the liver of Oujiang colored common carp Cyprinus carpio var. color. Fish Physiol Biochem. http://dx.doi.org/10.1007/s10695-010-9416-5.

LANGE, A., AUSSEIL, O., SEGNER, H. 2002, Alterations in tissue glutathione levels and metallothionein mRNA in rainbow trout during single and combined exposure to cadmium and zinc. Comp. Biochem. Physiol. Part C., 131: 231-243. http://dx.doi. org/10.1016/S1532-0456(02)00010-8.

MATÉS, J. M., 2000, Effects of antioxidant enzymes in the molecular control of reactive oxygen species toxicology. Toxicol., 153: 83104. PII: s0300-483x (00)00306-1.

OSSANA, N. A., EISSA, B. L., SALIBIÁN, A. 2009, Cadmium bioconcentration and genotoxicity in the common carp (Cyprinus carpio). Internat. J. Environ. Health, 3: 302- 309. http://dx.doi. org/10.1504/IJENVH.2009.028596.

PANDEY, S., AHMAD, I., PARVEZ, S., BIN-HAFEEZ, B., HAQUE, R., RAISUDDIN, S., 2001, Effect of endosulfan on antioxidants of freshwater fish Channa punctatus Bloch: 1. Protection against lipid peroxidation in liver by copper preexposure. Arch. Environ. Contam. Toxicol., 41: 345-352. http://dx.doi.org/10.1007/ s002440010258.

RICAN, O. \& KULLANDER, S. O., 2006, Character- and treebased delimitation of species in the 'Cichlasoma' facetum group (Teleostei, Cichlidae) with the description of a new genus. J. Zoolog. System. Evol. Res., 44: 136-152. http://dx.doi. org/10.1111/j.1439-0469.2005.00347.x.

SALIBIÁN, A., 2006, Ecotoxicological assessment of the highly polluted Reconquista River of Argentina. Rev. Environ. Contam.
Toxicol, 185: 35- 65. http://dx.doi.org/10.1007/0-387-3063822.

SEN, A. \& SEMIZ, A., 2007, Effects of metal and detergents on biotransformation and detoxification enzymes of leaping mullet (Liza saliens). Ecotoxicol. Environ. Safety, 68: 405-411. http:// dx.doi.org/10.1016/j.ecoenv.2006.08.007.

SRHN. 2003, Subsecretaria de Recursos Hídricos de la Nación. Desarrollos de Niveles Guía Nacionales de Calidad de Agua Ambiente correspondientes a Cadmio http://www. hidricosargentina.gov.ar/calidaddesarrollos. php

SONG, S. B., XU, Y., ZHOU, B. S., 2006, Effects of hexachlorobenzene on antioxidant status of liver and brain of common carp (Cyprinus carpio). Chemosphere, 65: 699-706. http://dx.doi.org/10.1016/j.chemosphere.2006.01.033.

TANAKA, K., SANO, T., ISHIZUKA, K., KITTA, K., KAWAMURA, K., 1994, Comparison of properties of leaf and root glutathione reductase from spinach. Physiol. Plant., 91: $353-$ 358. http://dx.doi.org/10.1111/j.1399-3054.1994.tb02960.x.

VERSTRAETEN, S. V., AIMO, L., OTEIZA, P. I., 2008, Aluminium and lead: molecular mechanisms of brain toxicity. Arch. Toxicol. 82: 789-802. http://dx.doi.org/10.1007/s00204-008-0345-3.

WIEGAND, C., PFLUGMACHER, S., OBEREMM, A., STEINBERG, C. E. W., 2000, Activity development of selected detoxication enzymes during the ontogenesis of the zebrafish (Danio rerio). Internat. Rev. Hydrobiol., 85: 413-422. http:// dx.doi.org/10.1002/1522-2632(200008)85:4.

ZAR, J. H. 1999, Biostatistical analysis. Prentice Hall, 4th Edition, New Jersey, USA. 